\title{
PERAMALAN GELOMBANG LAUT DANGKAL DAN HUBUNGANNYA DENGAN SEBARAN LIFEFORM KARANG DI PERAIRAN KOTA PADANG
}

\author{
SHALLOW WATER WAVES PREDICTION AND ITS RELATIONSHIP \\ WITH CORAL LIFEFORM IN PADANG CITY
}

\author{
Try Al Tanto ${ }^{1,2}$, I Wayan Nurjaya ${ }^{2}$, Dietriech G. Bengen2, Tri Hartanto ${ }^{2}$, \& Widodo S. Pranowo Wr4 $^{3,4}$ \\ ${ }^{1}$ Loka Riset Sumber Daya dan Kerentanan Pesisir, BRSDM KKP \\ ${ }^{2}$ Departemen Ilmu dan Teknologi Kelautan, FPIK, Institut Pertanian Bogor \\ ${ }^{3}$ Pusat Riset Kelautan, BRSDM KKP \\ ${ }^{4}$ Prodi Hidrografi, Sekolah Tinggi Teknologi Angkatan Laut \\ e-mail : try.altanto@gmail.com
}

Diterima tanggal: 21 April 2021 ; diterima setelah perbaikan: 25 April 20217 ; Disetujui tanggal: 27 April 2021

\begin{abstract}
ABSTRAK
Data gelombang laut penting untuk dikaji karena dapat mengakibatkan abrasi ataupun sedimentasi pada suatu pantai. Paramater gelombang laut juga dapat berperan secara tidak langsung terhadap bentuk lifeform karang. Kajian bertujuan untuk melakukan peramalan gelombang laut dangkal dari perhitungan data kecepatan dan arah angin permukaan, kemudian menghubungkan kejadian gelombang laut terhadap sebaran lifeform karang. Selama bulan April 2018, gelombang laut lebih tinggi terjadi pada awal dan akhir bulan. Karakteristik tinggi gelombang laut di wilayah kajian dominan dari angin dan dikuatkan oleh panjang fetch efektif arah angin bertiup. Terjadi hubungan erat antara parameter gelombang laut di lokasi kajian terhadap sebaran lifeform karang. Hasil analisis PCA dari sebaran gelombang laut di wilayah kajian memiliki nilai hubungan sebesar 79,23\%. Hasil analisis CA dari keterkaitan antara lifeform karang di wilayah kajian sebesar 74,40 \%. Tinggi gelombang laut maksimum di perairan P. Sirandah sebesar 1,07 m dengan periode $4.26 \mathrm{~s}$, terdapat karang jenis submassive (CS) dominan mencapai 77,33-85,27 \%. Kondisi gelombang laut di perairan P. Pasumpahan tidak menentu, secara umum rendah pada saat-saat air laut pasang dan surut waktu purnama dan perbani. Terdapat banyak jenis lifeform karang di perairan ini yaitu semua jenis karang non-Acropora dan Acropora jenis bercabang (ACB). Terumbu karang di perairan P. Sikuai dan P. Soronjong berada pada kondisi kurang baik (0,2-17,53 \%). Lifeform karang jenis submassive paling rendah pada ke dua pulau ini $(0,07 \%)$..
\end{abstract}

Kata kunci: Gelombang laut, perairan dangkal, lifeform karang, analisis PCA, analisis CA, Kota Padang.

\section{ABSTRACT}

Ocean waves data is important to be observed and monitor since its impact on the shorelines potentially generates abrasion or sedimentation. Ocean waves also affect indirectly on the coral lifeforms in the coastal areas. The study aims to forecast the ocean waves in coastal area based on surface wind speed and direction, then study its impact to the coral lifeform distribution in the study site. During April 2018, higher ocean waves usually occurred at the beginning and last days of the month. This high-ocean-waves phenomenon in the study site was largely caused by surface wind factor and it was indicated by the effective fetch length of surface wind direction. This study shows a strong relationship between ocean waves parameter and coral lifeform distribution. The PCA analysis obtained from the distribution of ocean waves variable in the study site was generating a correlation value of $79.23 \%$. While the CA analysis of the coral lifeform connectivity was $74.40 \%$. The maximum ocean wave height in Sirandah Island was $1.07 \mathrm{~m}$ with a period of $4.26 \mathrm{~s}$, and there was a dominant submassive coral that ranges from 77.33 to $85.27 \%$. On the other site, ocean waves height in Pasumpahan Island was unpredictable, usually low during high tide. There were many coral lifeforms found on this site, including all non-Acropora and branching Acropora species. The condition of coral reef cover surround Sikuai and Sironjong island were generally in poor state ranging from 0.2 to $17.53 \%$. While submassive corals in these two islands were the lowest $(0.07 \%)$.

Keywords: sea waves, shallow water, coral lifeform, PCA analysis, CA analysis, Padang City.

Peramalan Gelombang Laut Dangkal dan Hubungannya dengan Sebaran Lifeform Karang di Perairan Kota Padang - Try Al Tanto, I Wayan Nurjaya, Dietriech G. Bengen, Tri Hartanto, \& Widodo S. Pranowo 


\section{PENDAHULUAN}

Gelombang laut adalah pergerakan naik dan turunnya air laut dengan arah tegak lurus pemukaan air laut yang membentuk kurva/grafik sinusoidal (Holthuijsen, 2007). Sebagian besar gelombang di lautan terbentuk oleh energi yang ditimbulkan oleh tiupan angin (Kurniawan et al. 2011). Angin yang bertiup melintasi permukaan lautan menghasilkan sebagian besar gelombang di laut (Trujillo \& Thurman 2011). Gelombang laut pada kawasan pesisir umumnya dibangkitkan di laut lepas sebagai akibat interaksi antara angin dan permukaan laut. Gelombang biasanya mendekati pantai dengan kedudukan yang membentuk sudut terhadap garis pantai sedemikian rupa, sehingga gelombang menjadi agen pembangkit arus sejajar pantai (longshore current) sebagai akibat dari pengangkutan massa air ke badan pantai (Poerbandono, 2004). Penjalaran dari gelombang laut merupakan bentuk dari adanya gangguan pada suatu medium dalam air laut tersebut (Satriadi, 2017). Gelombang laut yang menjalar dari laut dalam menuju pantai akan terjadi pembelokan arah dan berusaha untuk tegak lurus dengan garis kontur dasar laut ketika memasuki perairan dangkal (Hidayat et al., 2013). Gelombang laut yang terjadi dapat bertambah tinggi kemudian menurun seiring dengan kontur kedalaman yang juga bertambah (Huda et al., 2015).

Data gelombang laut secara global mudah diakses, baik dari data ECMWF (Eropean Centre For MediumRange Weather Forcasts) dan Marine Copernicus. Hanya saja data yang tersedia tersebut dalam skala luas, grid paling kecil masih sekitar $9 \mathrm{Km}$. Hal ini menjadi batasan, terutama kajian dalam skala kecil untuk perairan dangkal di sekitar pulau-pulau kecil. Hal tersebut dapat diatasi diantaranya dengan perhitungan gelombang dengan data angin permukaan, permodelan gelombang laut dengan berbagai aplikasi, dan juga melakukan interpolasi dari data yang tersedia tersebut. Permodelan gelombang laut dapat menunjukkan efek shoaling, refraksi, difraksi, dan dissipasi energi (Sujantoko \& Natakusumah, 2003). Untuk peramalan gelombang laut dangkal dari data angin memerlukan data kedalaman pada titik peramalan. Selain itu juga memerlukan perhitungan panjang fetch efektif pada titik tersebut, merupakan salah satu faktor yang berpengaruh dominan dalam membangkitkan gelombang laut, selain kecepatan angin (speed) dan lama angin bertiup (duration). Dalam hal ini, peramalan gelombang laut dilakukan dengan perhitungan dengan data kecepatan dan arah angin.
Data gelombang laut penting dikaji, terutama di sekitar kawasan pesisir/pantai karena dapat memberikan dampak langsung, namun menyesuaikan terhadap bentuk pantainya. Laju transportasi sedimen salah satunya dipengaruhi oleh gelombang laut (Astuti et al. 2016). Pada beberapa keadaan, gelombang laut dapat mengakibat abrasi pantai. Seperti di perairan Eretan, karakteristik gelombang laut mampu menyebabkan abrasi pantai mencapai 1,5 m/tahun (Hadikusumah, 2009). Pantai Niampak Utara juga telah terjadi kejadian bencana abrasi sebagai akibat perubahan bentuk gelombang laut (Parauba et al. 2016). Namun beberapa kondisi juga dapat menyebabkan sedimentasi di pantai. Informasi gelombang laut juga penting untuk keperluan perlayaran. Terdapat jenis tertentu suatu kapal yang memiliki batas akibat suatu ketinggian gelombang, seperti pengoperasian Kapal Cepat Rudal 60M (Hardjono, 2018). Selain itu, paramater gelombang laut juga berperan secara tidak langsung terhadap bentuk pertumbuhan karang yang ada. Karang bercabang (branching) sering rusak dan tersebar akibat badai, namun karang massive cukup tahan terhadap kerusakan akibat badai tersebut (Hughes, 1987), termasuk juga hantaman dari gelombang tinggi. Karang foliose (CF) cukup rapuh dan mudah rusak oleh arus laut, terlebih lagi akibat hantaman gelombang laut tentunya jenis karang ini tidak dapat bertahan. Dalam hal ini, karang foliose melimpah pada air yang tenang dan sedikit lebih dalam (Hughes \& Jackson, 1985; Hughes 1987). Hubungan antara paramater gelombang laut terhadap terumbu karang cukup banyak ditemukan secara global (Gourlay \& Colleter ,2005; Storlazzi et al., 2005; Reidenbach et al., 2006; Jago et al., 2007; Huang et al., 2012; Hardy \& Young 2014; Kench dan Brander 2015; Pomeroy et al., 2015; Sreeranga \& Mendi, 2018). Namun kajian sejenis pada perairan Indonesia masih sangat minim, sehinga perlu dilakukan untuk melihat hubungan tidak langsung yang dapat terjadi tersebut. Tujuan kajian adalah melakukan peramalan tinggi gelombang laut yang terjadi di perairan dangkal, kemudian menentukan hubungannya dengan persebaran bentuk pertumbuhan (lifeform) karang di wilayah kajian.

\section{BAHAN DAN METODE}

Peramalan tinggi gelombang perairan dangkal dilakukan pada titik pengamatan terumbu karang, tersebar pada pulau-pulau kecil di Kota Padang (P. Pasumpahan, P. Sirandah, P. Sikuai, dan P. Sironjong). Data gelombang laut juga diperoleh dari data sekunder berupa data tinggi gelombang signifikan. Data tersebut diperoleh dari Eropean Centre For Medium-Range 


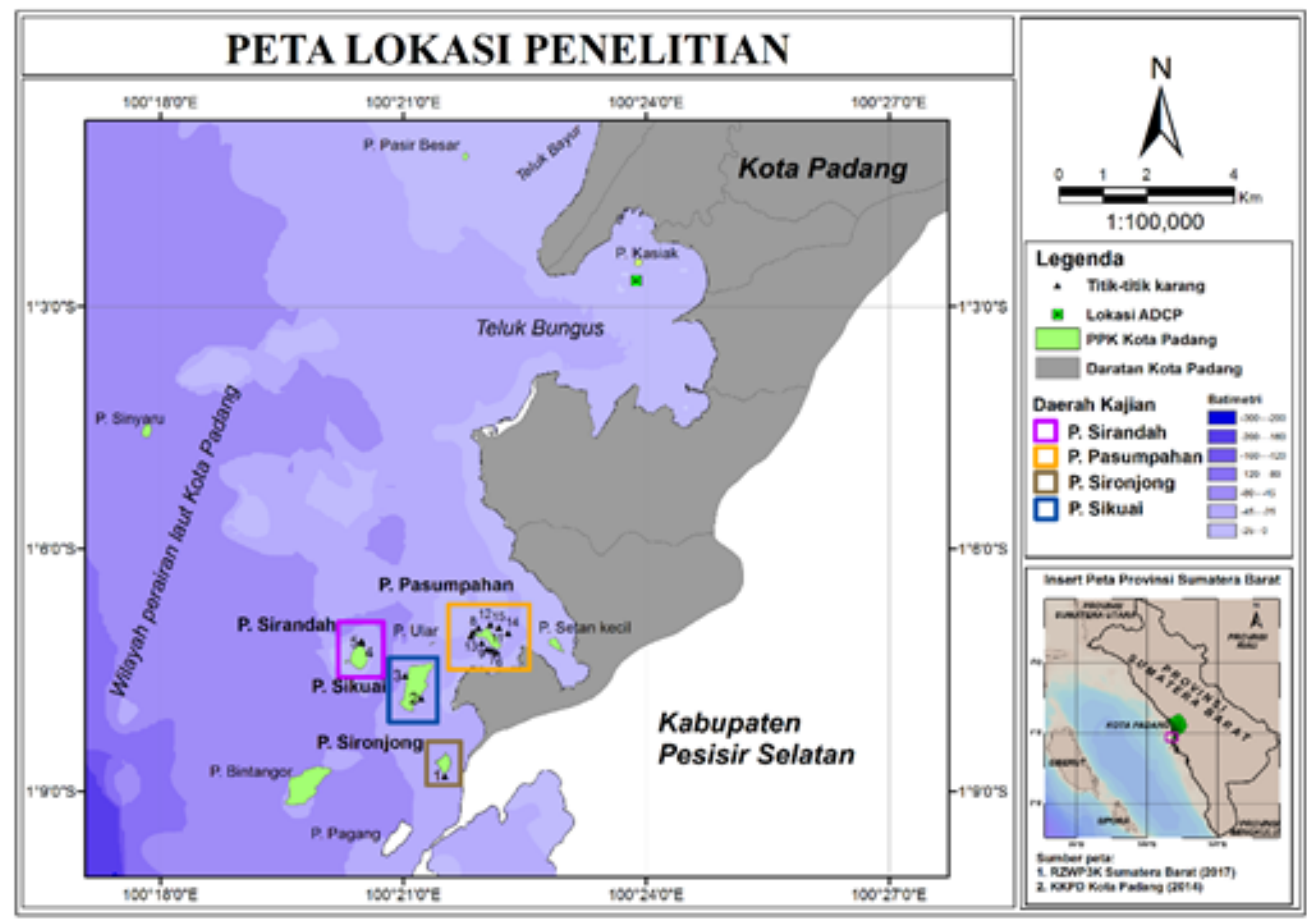

Gambar 1. Lokasi titik-titik kajian di PPK Kota Padang.

Figure 1. Location of study points in the PPK Kota Padang.

Weather Forcasts (ECMWF 2019) pada perairan bagian barat dari wilayah kajian (titik koordinat $100,25^{\circ} \mathrm{BT}$ dan $1,125^{\circ} \mathrm{LS}$ ), serta data Marine Copernicus (The European Union Copernicus 2020) pada bagian utara wilayah kajian (titik koordinat $100,333^{\circ} \mathrm{BT}$ dan $1,083^{\circ}$ LS) dan bagian selatan (titik koordinat $100,333^{\circ} \mathrm{BT}$ dan $\left.1,167^{\circ} \mathrm{LS}\right)$.

Data gelombang laut diambil selama tahun 2018, untuk melihat kondisi gelombang secara umum. Selain itu, data tinggi gelombang laut dihitung berdasarkan data angin permukaan u dan v, saat musim peralihan I (bulan April 2018). Kajian pada musim peralihan I (bulan april) dilakukan karena pada saat tersebut kejadian gelombang laut masih lebih rendah (Kurniawan et al., 2011), merupakan kondisi paling aman untuk penyelaman. Peramalan gelombang laut dilakukan pada titik-titik pengamatan terumbu karang di wilayah kajian.

Sebelum melakukan perhitungan komponen gelombang dari data angin, perlu melakukan beberapa koreksi terhadap data angin, yaitu koreksi durasi, koreksi pengukuran angin dari darat ke laut, dan koreksi stabilitas. Koreksi ketinggian tidak dilakukan karena data angin sudah pada ketinggian $10 \mathrm{~m}$. Berikut persamaan yang digunakan dalam koreksi yang dilakukan tersebut (Department of The Army, 2003):

$$
\mathrm{t}=\frac{1609}{\mathrm{U}_{\mathrm{f}}} \quad ; \text { untuk satuan } \mathrm{m} / \mathrm{s}
$$

$$
\frac{\mathrm{U}_{\mathrm{t}}}{\mathrm{U}_{3600}}=1.277+0.296 * \tanh \left\{0.9 \log _{10}\left(\frac{45}{\mathrm{t}}\right)\right\}
$$

untuk $\mathrm{t}<3600$

$$
\frac{U_{t}}{U_{3600}}=-0.15 \log _{10} t+1.5334
$$

untuk $3600<\mathrm{t}<36000$

$$
\mathrm{U}_{\mathrm{t}=3600}=\frac{\mathrm{U}_{\mathrm{f}}}{\left(\frac{\mathrm{U}_{\mathrm{t}}}{\mathrm{U}_{3600}}\right)}
$$

$\mathrm{t}$ durasi angin dalam (dt); Uf kecepatan angin sebelum koreksi durasi (setelah koreksi ketinggian); U3600 kecepatan angin dalam 1 jam (setelah koreksi durasi). Koreksi pengukuran angin dari darat ke laut:

$$
\mathrm{R}_{\mathrm{L}}=2.1245^{*}\left(\mathrm{U}_{\mathrm{t}=3600} \wedge(-0.2708)\right)
$$


Koreksi stabilitas:

$$
\begin{aligned}
& \mathrm{U}_{\mathrm{W}}=\mathrm{R}_{\mathrm{L}} * \mathrm{U}_{\mathrm{t}=3600} \\
& \mathrm{U}_{\mathrm{c}}=\mathrm{R}_{\mathrm{T}} \mathrm{U}_{\mathrm{W}} \\
& \mathrm{U}_{\mathrm{a}}=0.71 * \mathrm{U}_{\mathrm{c}}^{1.23}
\end{aligned}
$$

Uc kecepatan angin setelah koreksi stabilitas, Ua wind stress factor, UW kecepatan angin sebelum koreksi stabilitas, RT koefisien beda suhu udara - air laut (RT $=1,1)$.

Selanjutnya dilakukan penentuan fetch. Perhitungan fetch efektif ( $f e f f)$ hanya dilakukan pada saat arah angin cukup dominan. Jika panjang fetch lebih dari $200 \mathrm{~km}$, maka panjang fetch maksimal yang digunakan adalah $200 \mathrm{~km}$. untuk perhitungan tinggi dan periode gelombang digunakan persamaan berikut (Department of The Army 2003):

$$
\begin{aligned}
& \frac{\mathrm{gH}_{\mathrm{mo}}}{\mathrm{U}_{*}^{2}}=4.13 * 10^{-2} *\left(\frac{\mathrm{gX}}{\mathrm{U}_{*}^{2}}\right)^{1 / 2} \\
& \frac{\mathrm{gT}_{\mathrm{p}}}{\mathrm{U}_{*}}=0.651 *\left(\frac{\mathrm{gX}}{\mathrm{U}_{*}^{2}}\right)^{1 / 3} \\
& \mathrm{C}_{\mathrm{D}}=\frac{\mathrm{U}_{*}^{2}}{\mathrm{U}_{10}^{2}} \text { atau } \mathrm{U}_{*}=\sqrt{\mathrm{C}_{\mathrm{D}} \mathrm{U}_{10}^{2}} \\
& \mathrm{C}_{\mathrm{D}}=0.001\left(1.1+0.035 \mathrm{U}_{10}\right)
\end{aligned}
$$

$\mathrm{H}_{\mathrm{mo}}=$ tinggi gelombang signifikan; $\mathrm{T}_{\mathrm{p}}=$ periode gelombang laut; $\mathrm{X}=$ jarak fetch dari mana angin berhembus; $\mathrm{U}_{10}=$ kecepatan angin pada ketinggian $10 \mathrm{~m} ; \mathrm{U}_{*}=$ kecepatan friksi "friction velocity"; $\mathrm{CD}=$ koefisien gesekan "drag coeficient".

Persamaan untuk kondisi gelombang fully developed dapat ditulis secara sederhana seperti berikut:

$$
\begin{aligned}
& \frac{\mathrm{gH}_{\mathrm{m}}}{\mathrm{U}_{*}^{2}}=2.115^{*} 10^{2} \\
& \frac{\mathrm{gT}_{\mathrm{p}}}{\mathrm{U}_{*}}=2.398 * 10^{2}
\end{aligned}
$$

Untuk perairan laut dangkal, menggunakan persamaan berikut (WMO 1998):

$$
\begin{aligned}
& H^{*}= 0.283^{*}\left(\frac{\mathrm{U}_{\mathrm{a}}^{2}}{\mathrm{~g}}\right) \tanh \left[0.52\left(\frac{\mathrm{gh}}{\mathrm{U}_{\mathrm{a}}^{2}}\right)^{3 / 4}\right] \\
& \tanh \left[\frac{\left.\left(\frac{0.0016}{0.283}\right)\left(\frac{\mathrm{gX}}{\mathrm{U}_{\mathrm{a}}^{2}}\right)^{1 / 2}\right]}{\tanh \left(0.53\left(\frac{\mathrm{gh}}{\mathrm{U}_{\mathrm{a}}^{2}}\right)^{3 / 4}\right)}\right] / \\
& T^{*}=7.54 *\left(\frac{\mathrm{U}_{\mathrm{a}}}{\mathrm{g}}\right) \tanh \left[0.833\left(\frac{\mathrm{gh}}{\mathrm{U}_{\mathrm{a}}^{2}}\right)^{3 / 8}\right] \\
& \tanh \left[\frac{\left(\frac{0.2857}{7.54}\right)\left(\frac{\mathrm{gX}}{\mathrm{U}_{\mathrm{a}}^{2}}\right)^{1 / 3}}{\tanh \left(0.833\left(\frac{\mathrm{gh}}{\mathrm{U}_{\mathrm{a}}^{2}}\right)^{3 / 8}\right)}\right]
\end{aligned}
$$

Hasil peramalan tinggi gelombang laut selama April 2018, dicuplik pada saat kondisi pasang purnama, pasang perbani, surut purnama, dan surut perbani. Sebaran tinggi gelombang laut pada titik-titik karang tersebut dilakukan pengujian secara statistik dengan analisis komponen utama (PCA). Kemudian hubungan antara bentuk pertumbuhan karang pada titik-titik kajian dilakukan analisis koresponden (CA). Dengan analisis PCA dan CA ini, dapat diperoleh hubungan antara tinggi gelombang laut terhadap sebaran bentuk pertumbuhan karang di wilayah kajian.

\section{HASIL DAN PEMBAHASAN}

.Data hasil peramalan/model tinggi gelombang signifikan dari Marine Copernicus dan ECMWF selama tahun 2018 di perairan PPK Kota Padang, menunjukkan perbedaan nilai tinggi gelombang yang terjadi. Lokasi titik-titik peramalan gelombang yang diperoleh tersebut berada di bagian utara (koordinat $100,333^{\circ} \mathrm{BT}$ dan $1,083^{\circ} \mathrm{LS}$ ), bagian selatan (koordinat $100,333^{\circ} \mathrm{BT}$ dan $\left.1,167^{\circ} \mathrm{LS}\right)$, serta bagian barat (koordinat $100,25^{\circ} \mathrm{BT}$ dan $1,125^{\circ} \mathrm{LS}$ ). Secara umum karakteristik gelombang yang berasal dari bagian barat (Gambar 2: garis merah) lebih besar dibandingkan dengan bagian selatan (Gambar 2: garis kuning) dan bagian utara (Gambar 2: garis biru). Gelombang laut yang terjadi pada bagian barat berada cukup jauh di laut lepas, sedangkan kejadian gelombang laut pada bagian utara dan selatan lebih dekat ke arah PPK Kota Padang. Selama April 2018, gelombang laut dalam di bagian barat mencapai ketinggian 0,56 - 1,4 m (Gambar 2: garis merah tebal), sedangkan bagian utara mencapai 


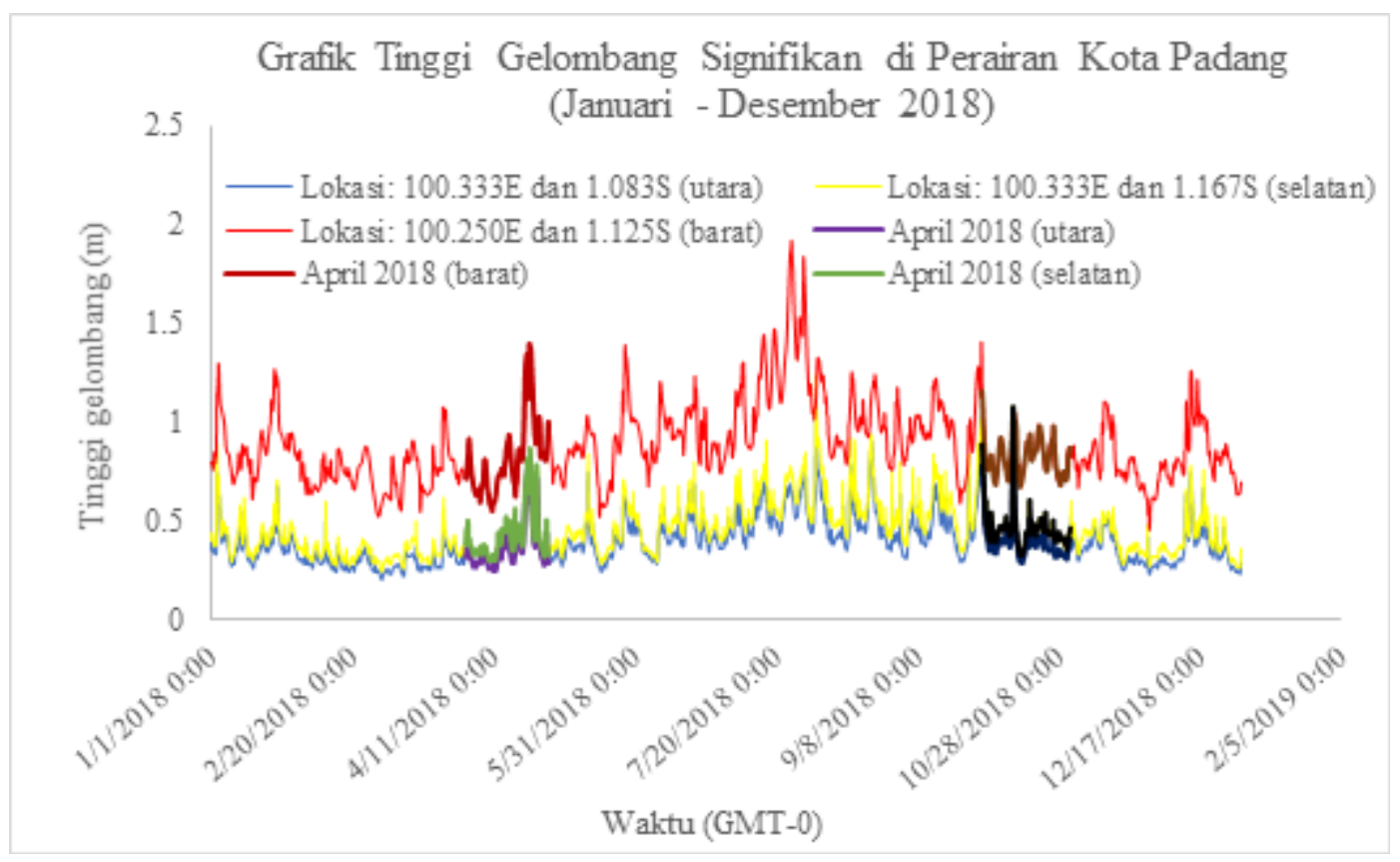

Gambar 2. Grafik tinggi gelombang signifikan pada wilayah kajian di perairan PPK Kota Padang selama tahun 2018.

Figure 2. Graph of significant wave height in the study area in the KDP waters of Padang City during 2018.

$0,25-0,81 \mathrm{~m}$ (Gambar 2: garis ungu tebal) dan bagian selatan 0,3-0,86 m (Gambar 2: garis hijau tebal).

Nilai peramalan tinggi gelombang signifikan dari data angin permukaan, dilakukan pada titik-titik pengamatan terumbu karang yang berada pada perairan dangkal. Hal ini memerlukan data kedalaman perairan di lokasi peramalan yang dilakukan. Hasil nilai kedalaman diperoleh saat pengamatan terumbu karang dan juga dari peta batimetri yang dihasilkan (Tabel 1). Selain itu juga memperhitungkan panjang fetch efektif (Tabel 1), merupakan salah satu faktor yang berpengaruh dominan dalam membangkitkan gelombang laut, selain kecepatan angin (speed) dan lama angin bertiup (duration).

Secara khusus pada titik-titik pengamatan terumbu karang, hasil peramalan gelombang laut pada perairan dangkal tidak terdapat perbedaan pola kejadian gelombang laut secara signifikan dari masing-masing lokasi kajian (Gambar 2). Secara umum pola kejadian gelombang laut pada April 2018, lebih tinggi terjadi pada awal-awal dan akhir bulan. Sedangkan pada pertengahan bulannya, gelombang laut yang terjadi cenderung lebih rendah. Namun dari karakteristik parameter gelombang laut selama musim peralihan I (April 2018) (Gambar 4), terlihat sedikit perbedaan. Terutama pada perairan P. Sikuai (T-TG), memiliki tinggi gelombang maksimal paling rendah diantara titik-titik kajian lainnya. Tinggi gelombang signifikan di lokasi ini yaitu sebesar $0,31 \mathrm{~m}$ dan rata-rata sebesar $0,06 \mathrm{~m}$, periode gelombang maksimum selama $2,25 \mathrm{~s}$ (Tabel 2). Hal ini dapat terjadi karena titik pengamatan di P. Sikuai (T-TG) ini cukup terlindungi dan jauh dari pengaruh dinamika laut lepas. Lokasi ini berada pada bagian dalam, pembangkit utama gelombang laut dominan berasal dari arah selatan dan barat daya, memiliki panjang fetch yang paling pendek diantara posisi lainnya. Panjang fetch efektif terjauh saat gelombang maksimum tersebut adalah 17,43 Km (Tabel 1) berasal dari arah selatan. Kondisi terumbu karang di lokasi ini sangat mengkhawatirkan, dengan tutupan karang hidup yang ditemukan sangat rendah, sebesar $0,20 \%$. Hanya keberadaan lifeform karang jenis encrusting (CE) yang ditemukan pada lokasi ini. Kedekatan hubungan lokasi dengan gelombang laut terjadi saat air laut pasang dan surut kondisi purnama (Gambar 7). Pada saat-saat tersebut kejadian gelombang laut sangat rendah. Hanya saja keberadaan lifeform karang tidak terlihat hubungan yang signifikan terhadap kejadian gelombang laut di lokasi ini (Gambar 8).

Titik kajian di P. Sikuai lainnya (B-BL), memiliki tinggi gelombang laut maksimum sebesar $0.80 \mathrm{~m}$ dengan periode $3,71 \mathrm{~s}$ dan rata-rata bulanan $0.16 \mathrm{~m}$. Nilai tinggi gelombang laut titik B-BL ini lebih besar dibandingkan dari kejadian di bagian T-TG, karena cukup mendapat pengaruh dari gelombang laut yang berasal dari bagian barat maupun sebelah utara wilayah 
Tabel 1. Panjang Fetch efektif dan informasi kedalaman perairan pada titik-titik kajian (pengamatan karang) Table 1. Effective Fetch Length and water depth information at study points (coral observations)

\begin{tabular}{|c|c|c|c|c|c|}
\hline No & Arah angin bertiup & Fetch $_{\text {eff }}(\mathrm{m})$ & No & Arah angin bertiup & Fetcheff (m) \\
\hline & Sironjong (S), $8 \mathrm{~m}$ & & Past & ahan (U-BL), $8 \mathrm{~m}$ & \\
\hline 1 & SELATAN & 1768.88 & 1 & UTARA & 3413.00 \\
\hline 2 & BARAT DAYA & 75191.07 & 2 & BARAT DAYA & 15074.33 \\
\hline 3 & BARAT & 108906.70 & 3 & BARAT & 118594.89 \\
\hline \multirow[t]{2}{*}{4} & BARAT LAUT & 134611.49 & 4 & BARAT LAUT & 127463.57 \\
\hline & Sikuai (B-BL), 6 m & & Past & ahan (BD), $8 \mathrm{~m}$ & \\
\hline 1 & UTARA & 22706.47 & 1 & BARAT DAYA & 1920.00 \\
\hline 2 & SELATAN & 38069.67 & 2 & BARAT & 80291.47 \\
\hline 3 & BARAT DAYA & 113293.12 & 3 & BARAT LAUT & 84062.30 \\
\hline 4 & BARAT & 97661.05 & Past & ahan (S-BD), $8 \mathrm{~m}$ & \\
\hline \multirow[t]{2}{*}{5} & BARAT LAUT & 77154.36 & 1 & BARAT DAYA & 2218.00 \\
\hline & Sikuai (T-TG), 7 m & & 2 & BARAT & 6146.50 \\
\hline 1 & SELATAN & 17433.70 & 3 & BARAT LAUT & 50317.80 \\
\hline \multirow[t]{2}{*}{2} & BARAT DAYA & 14707.00 & Past & ahan (U), $10 \mathrm{~m}$ & \\
\hline & Sirandah (U-TL1), $10 \mathrm{~m}$ & & 1 & UTARA & 2640.00 \\
\hline 1 & UTARA & 24686.45 & 2 & BARAT & 118250.73 \\
\hline 2 & BARAT DAYA & 94536.54 & 3 & BARAT LAUT & 133615.78 \\
\hline 3 & BARAT 163481.08 & & & Pasumpahan (S2), $5 \mathrm{~m}$ & \\
\hline \multirow[t]{2}{*}{4} & BARAT LAUT & 95119.02 & 1 & BARAT & 46867.28 \\
\hline & Sirandah (U-TL2), 7 m & & 2 & BARAT LAUT & 6568.65 \\
\hline 1 & UTARA 24959.21 & & Past & ahan (B), $8 \mathrm{~m}$ & \\
\hline 2 & BARAT DAYA & 58648.23 & 1 & UTARA & 15288.26 \\
\hline 3 & BARAT & 162084.39 & 2 & BARAT DAYA & 1362.00 \\
\hline \multirow[t]{2}{*}{4} & BARAT LAUT & 177886.81 & 3 & BARAT & 97422.76 \\
\hline & Pasumpahan (S1), $10 \mathrm{~m}$ & & 4 & BARAT LAUT & 66239.14 \\
\hline 1 & BARAT DAYA & 477.00 & Past & $\operatorname{ahan}(\mathrm{T}), 7 \mathrm{~m}$ & \\
\hline 2 & BARAT & 39932.61 & 1 & UTARA & 10738.369 \\
\hline \multirow[t]{2}{*}{3} & BARAT LAUT & 79463.07 & 2 & BARAT & 43528.87341 \\
\hline & Pasumpahan (BL), $8 \mathrm{~m}$ & & 3 & BARAT LAUT & 86146.27992 \\
\hline 1 & UTARA & 69273.75 & Past & ahan (TL), $7 \mathrm{~m}$ & \\
\hline 2 & BARAT DAYA & 59319.16 & 1 & UTARA & 14572.86 \\
\hline 3 & BARAT & 137332.73 & 2 & BARAT & 101278.52 \\
\hline 4 & BARAT LAUT & 120334.70 & 3 & BARAT LAUT & 106690.03 \\
\hline
\end{tabular}

Sumber: Hasil pengolahan data (2020)

kajian. Gelombang laut dalam yang berasal dari arah barat wilayah kajian memiliki ketinggian lebih besar (Gambar 2) dari bagian lainnya (utara dan selatan). Pada saat kejadian gelombang laut maksimum tersebut, kejadian angin juga paling tinggi terjadi selama bulan April $2018(5,4 \mathrm{~m} / \mathrm{s})$ dengan panjang fetch efektif sejauh 97,66 Km (Tabel 1).

Gelombang laut paling tinggi terjadi pada perairan P. Sirandah (U-TL), mencapai maksimal sebesar 0,91 $\mathrm{m}$ dengan periode 4,01 s (titik 2) dan 1,07 m dengan periode 4,26 s (titik 1), serta rata-rata sebesar $0,18 \mathrm{~m}$. Pada saat gelombang maksimum tersebut, kecepatan angin mencapai paling besar selama 1 bulan kajian yaitu $5,4 \mathrm{~m} / \mathrm{s}$ (westerly). Panjang fetch efektif pada saat kejadian tersebut adalah sejauh $162,08 \mathrm{Km}$ (titik 2) dan $163,48 \mathrm{Km}$ (titik 1) (Tabel 1). Dengan nilai kecepatan angin kisaran 5,2-8,1 $\mathrm{m} / \mathrm{s}$ dapat membangkitkan gelombang laut mencapai ketinggian $1,5 \mathrm{~m}$ (Trujillo \& Thurman, 2011), sehingga kejadian gelombang laut di lokasi ini sangat besar kemungkinan terjadinya. Pada saat air laut pasang dan surut (purnama dan perbani) di lokasi ini juga memiliki tinggi gelombang lebih besar dari lokasi lainnya. Kondisi kehidupan karang di lokasi ini menandakan kondisi yang baik dengan \% tutupan karang hidup sebesar 77,33-85,27 \% (Gambar 6), yaitu lifeform karang jenis submassive (CS). Hal ini menjadikan kedekatan hubungan gelombang laut yang terjadi tersebut (hasil PCA dan CA) dengan lokasi kajian di P. Sirandah (Gambar 7 dan 8). 


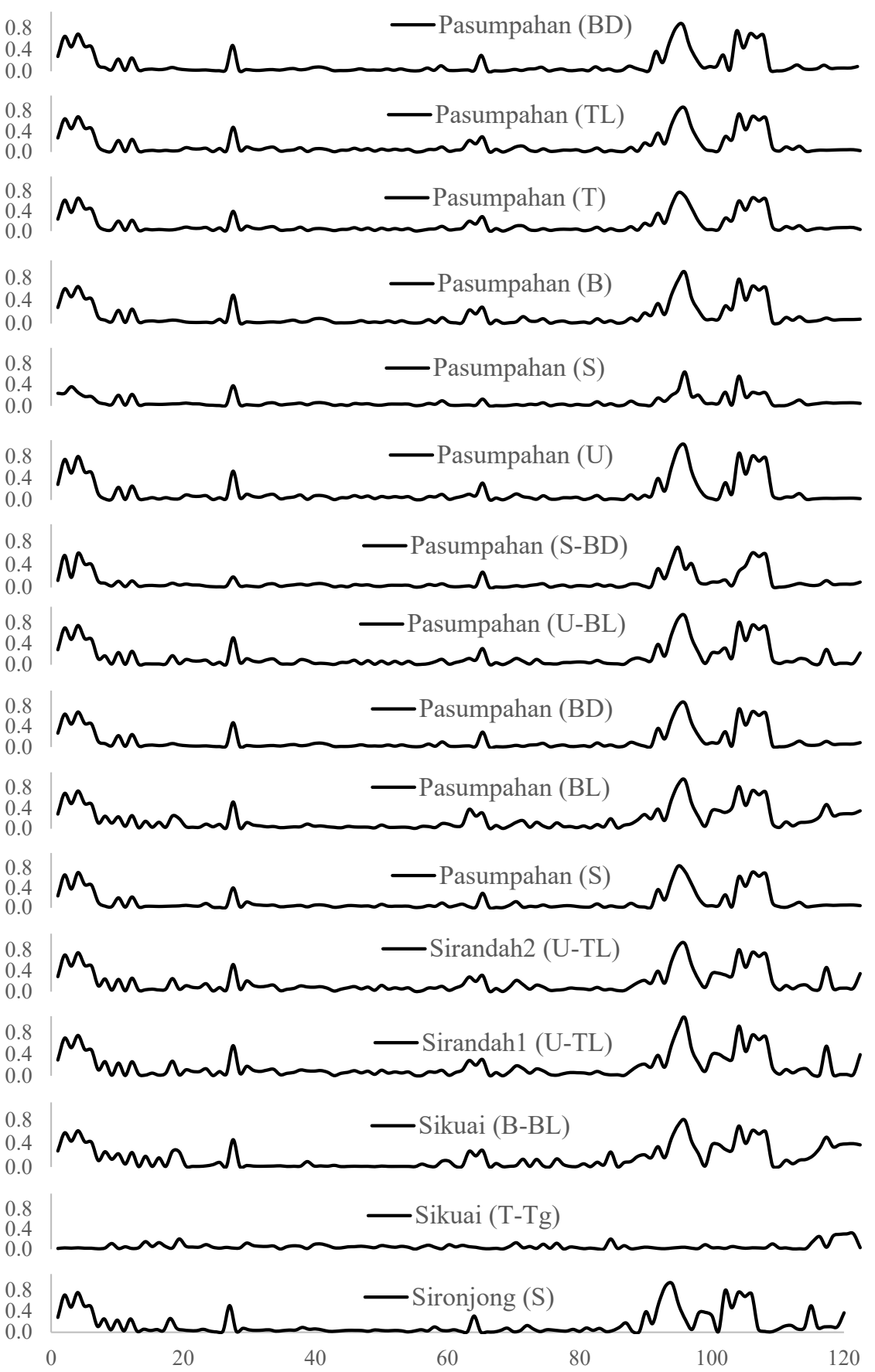

Gambar 3. Grafik tinggi gelombang signifikan pada titik-titik pengamatan karang selama bulan April 2018 di PPK Kota Padang.

Figure 3. Graph of significant wave height at coral observation points during April 2018 at KDP Padang City Kota.

Titik pengamatan pada perairan bagian selatan $\mathrm{P}$. Sironjong juga memiliki kejadian gelombang laut cukup besar, mencapai 0,92 m (maksimum) dengan periode 3,93 s dan rata-rata tinggi gelombang sebesar $0,15 \mathrm{~m}$. Hal ini juga terkait dengan gelombang laut dalam yang berasal dari selatan juga masih lebih besar dibandingkan gelombang bagian utara, walaupun lebih rendah dibandingkan bagian barat. Tentunya titik kajian pada P. Sironjong ini sangat mendapat pengaruh oleh penjalaran gelombang dari bagian selatan wilayah kajian (Gambar 2: garis jingga tebal). Kejadian maksimum gelombang pada titik ini juga terjadi pada saat kejadian angin maksimum $(5,4 \mathrm{~m} / \mathrm{s})$, dengan panjang fetch efektif $108,91 \mathrm{Km}$ (Tabel 1). Hanya saja, pada lokasi ini kondisi karang tidak baik dengan \% tutupan terumbu karang paling rendah yaitu $0,54-2,97$ $\%$ (Gambar 6). Keberadaan lifeform karang bercabang paling tinggi sebesar $2,04 \%$ dan paling rendah jenis 


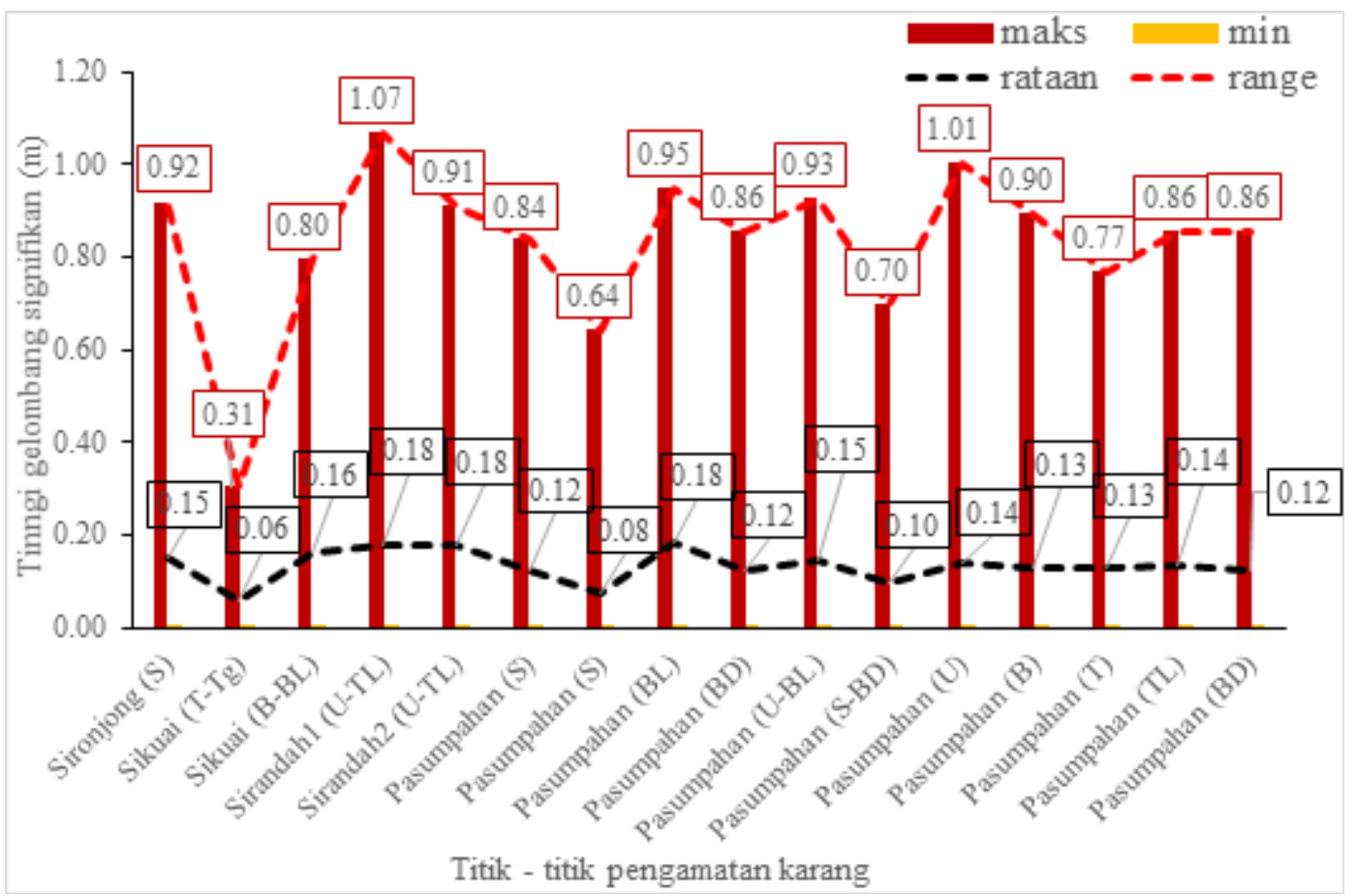

Gambar 4. Grafik karakteristik tinggi gelombang laut pada titik-titik pengamatan karang saat musim peralihan I (April 2018) di PPK Kota Padang.

Figure 4. Graph of the characteristics of sea wave heights at coral observation points during the transitional season I (April 2018) at PPK Padang City.

Tabel 1. Panjang Fetch efektif dan informasi kedalaman perairan pada titik-titik kajian (pengamatan karang) Table 1. Effective Fetch Length and water depth information at study points (coral observations)

\begin{tabular}{llll}
\hline \multirow{2}{*}{ Lokasi kajian } & \multicolumn{3}{c}{ Periode gelombang (s) } \\
& Maks & Min & Rata-rata \\
\hline Sironjong (S) & 3,93 & 0,27 & 1,28 \\
Sikuai (T-Tg) & 2,25 & 0,19 & 0,81 \\
Sikuai (B-BL) & 3,71 & 0,22 & 1,32 \\
Sirandah1 (U-TL) & 4,26 & 0,20 & 1,46 \\
Sirandah2 (U-TL) & 4,01 & 0,29 & 1,51 \\
Pasumpahan (S-1) & 3,72 & 0,27 & 1,12 \\
Pasumpahan (S-2) & 3,26 & 0,21 & 0,90 \\
Pasumpahan (BL) & 4,04 & 0,34 & 1,50 \\
Pasumpahan (BD) & 3,77 & 0,25 & 1,09 \\
Pasumpahan (U-BL) & 3,97 & 0,21 & 1,26 \\
Pasumpahan (S-BD) & 3,37 & 0,23 & 1,01 \\
Pasumpahan (U) & 4,10 & 0,22 & 1,21 \\
Pasumpahan (B) & 3,87 & 0,23 & 1,16 \\
Pasumpahan (T) & 3,59 & 0,29 & 1,21 \\
Pasumpahan (TL) & 3,82 & 0,26 & 1,23 \\
Pasumpahan (BD) & 3,77 & 0,25 & 1,09 \\
\hline
\end{tabular}

CS sebesar $0,07 \%$. Tidak terlihat pengaruh gelombang laut terhadap keberadaan lifeform karang di perairan ini (Gambar 7 dan 8).

Perairan P. Pasumpahan memiliki kejadian gelombang laut hampir seragam, nilai rata-rata tinggi gelombang signifikan sebesar $0,08-0,18 \mathrm{~m}$. Perbedaan terjadi saat kejadian tinggi gelombang laut mencapai nilai maksimum. Kejadian gelombang laut paling tinggi terjadi pada titik pengamatan karang bagian utara yaitu mencapai 1,01 m (Gambar4) dengan periode selama 4,1 s (Tabel 1). Pada saat tersebut kejadian angin sebagai 


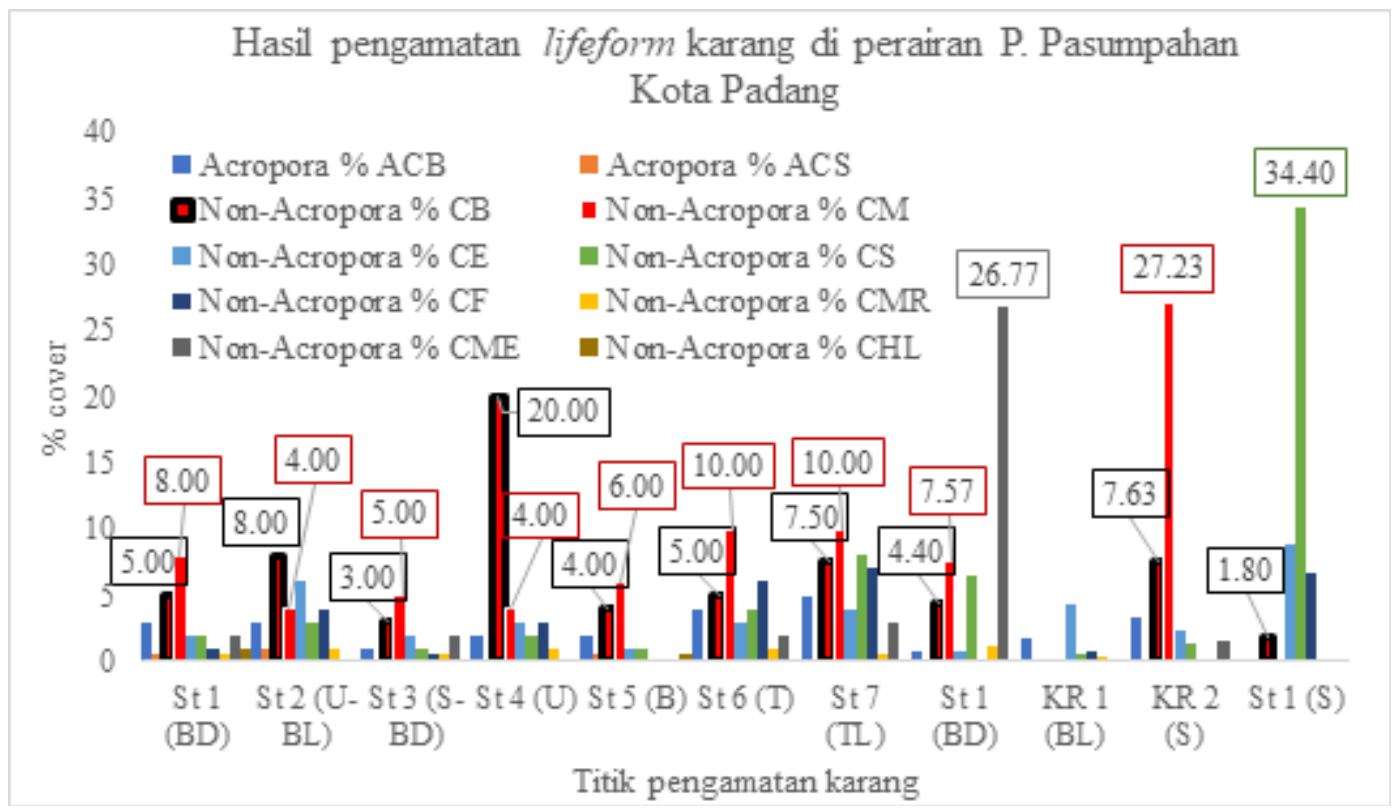

Gambar 5. Hasil pengamatan lifeform karang perairan P. Pasumpahan, Kota Padang.

Figure 5. Observations of coral lifeforms in Pasumpahan waters, Padang City.

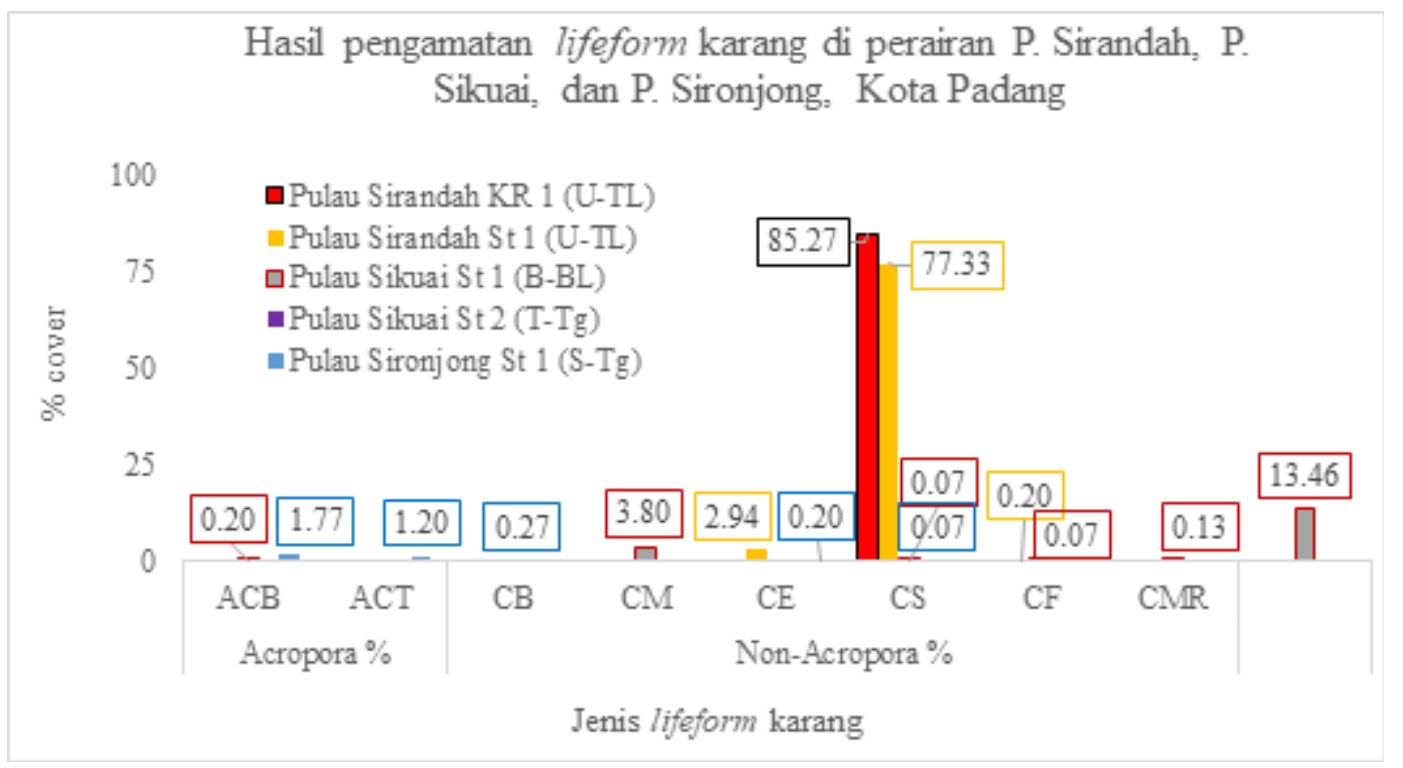

Gambar 6. Hasil pengamatan lifeform karang di perairan P. Sirandah, P. Sikuai, dan P. Sironjong, Kota Padang. Figure 6. Observations of coral lifeforms in the waters of Sirandah Island, Sikuai Island, and Sironjong Island, Padang City

pembangkit utama gelombang laut mencapai kecepatan $5,4 \mathrm{~m} / \mathrm{s}$ dengan arah berasal dari barat (westerly). Nilai kecepatan angin ini juga merupakan yang paling besar terjadi dalam rentang kejadian selama April 2018. Bahkan dengan nilai kecepatan angin kisaran 5,2-8,1 $\mathrm{m} / \mathrm{s}$ dapat membangkitkan gelombang laut mencapai ketinggian 1,5 m (Trujillo \& Thurman, 2011). Selain itu, saat kejadian gelombang besar ini, panjang fetch efektif dari arah angin tersebut juga cukup jauh yaitu 118,25 Km (Tabel 1). Kejadian gelombang paling rendah terjadi di bagian selatan P. Pasumpahan, dengan rata-rata tinggi gelombang selama April 2018 sebesar $0,08 \mathrm{~m}$, dan tinggi gelombang maksimum sebesar 0,66 $\mathrm{m}$ dengan periode selama 3,26 s. Pada titik lokasi ini memang cukup terlindungi, sehingga panjang fetch efektif dari kecepatan angin yang dapat membangkitkan gelombang terbatas. Pada saat gelombang maksimum di titik ini, kejadian angin juga paling maksimum $(5,4$ $\mathrm{m} / \mathrm{s}$ ), hanya saja panjang fetch efektif dari arah angin tersebut hanya sejauh $46,87 \mathrm{Km}$ (Tabel 1). Pada titik- 


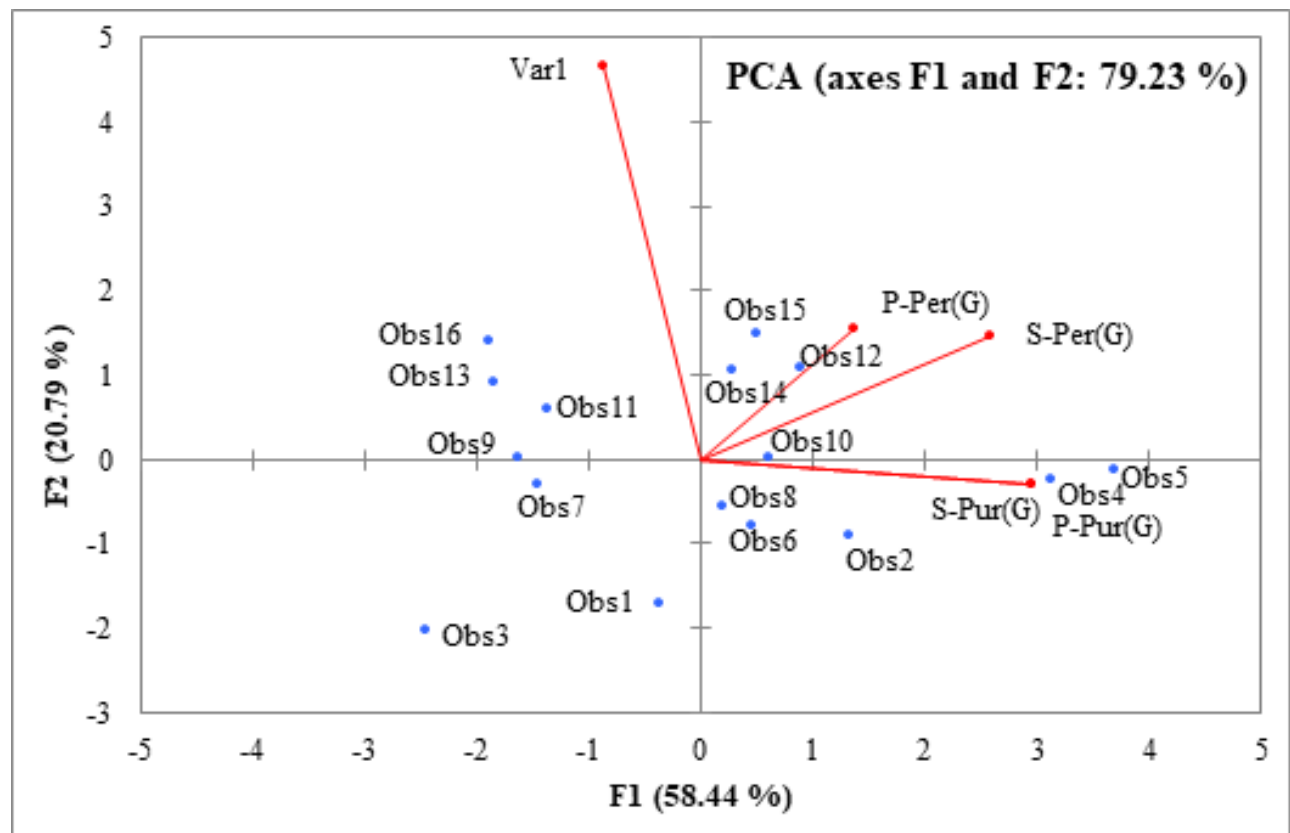

Gambar 7. Hasil pengamatan lifeform karang di perairan P. Sirandah, P. Sikuai, dan P. Sironjong, Kota Padang. Figure 7. Results of PCA analysis: distribution of sea wave variables at coral observation points in PPK waters of Padang City.

titik lainnya di P. Pasumpahan cukup merata dengan nilai tinggi gelombang maksimum sebesar $0,70-0,95$ $\mathrm{m}$ dan periode gelombang 3,37-4.04 s (Tabel 2). Keberadaan lifeform karang di perairan ini cukup merata pada titik-titik kajian, secara umum karang non-Acropora lebih banyak ditemukan. Dominansi keberadaan lifeform karang bercabang (ACB dan $\mathrm{CB}$ ) dan karang massive (CM), yang dapat ditemukan pada setiap titik pengamatan di perairan ini (Gambar 5). Tutupan karang hidup di perairan ini masih dalam keadaan yang baik, berkisar antara 7,70-51,87 \%. Kondisi gelombang laut yang umumnya rendah di perairan ini tidak memperlihatkan pengaruh signifikan terhadap keberadaan terumbu karang (Gambar 7 dan 8). Hanya beberapa titik saja yang memiliki kedekatan hubungan, seperti bagian selatan (Obs6), terdapat

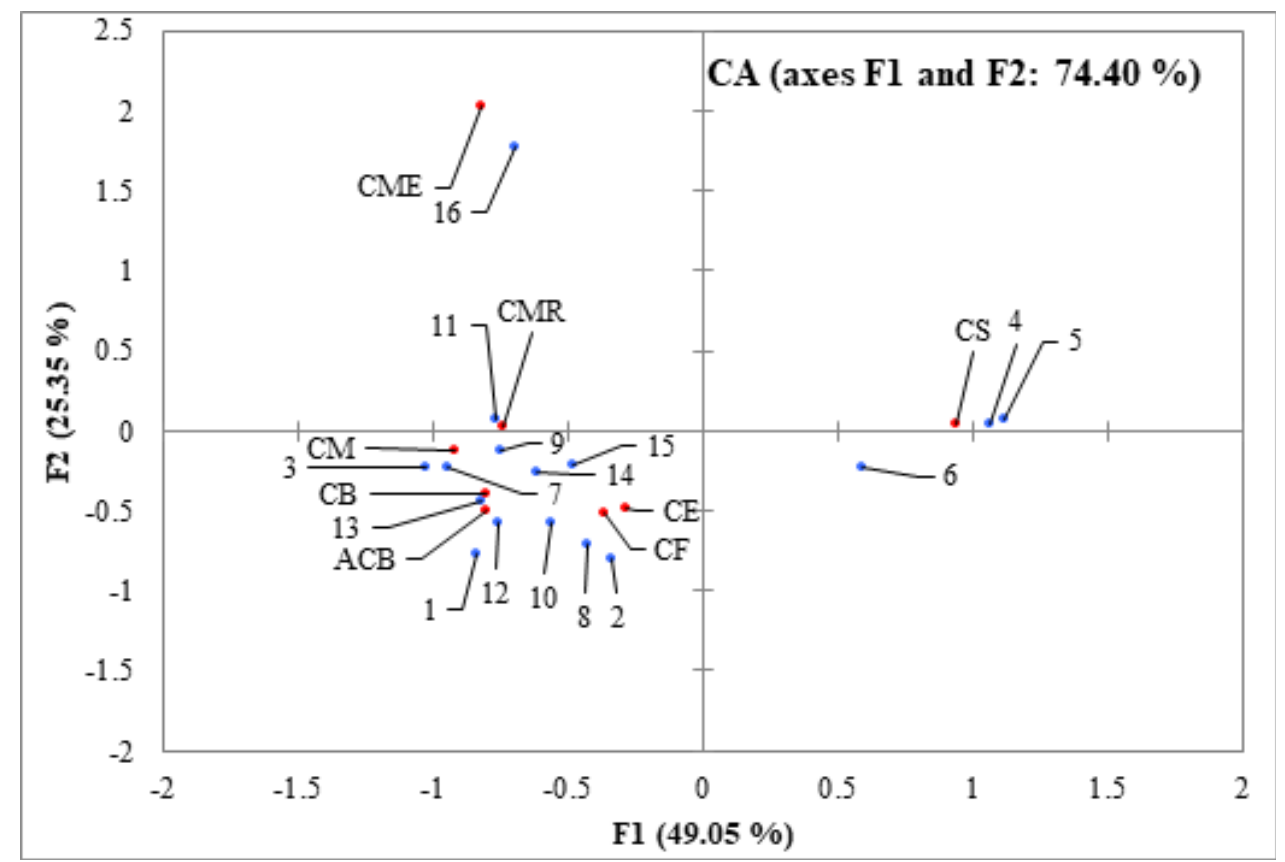

Gambar 7. Hasil pengamatan lifeform karang di perairan P. Sirandah, P. Sikuai, dan P. Sironjong, Kota Padang. Figure 7. CA analysis results: the relationship between the presence of coral lifeforms in the study area in Padang City KDP waters. 
keberadaan karang CS cukup dominan (Gambar 8). Pada lokasi ini, gelombang laut mencapai maksimum sebesar 0,835 $\mathrm{m}$ dengan periode 3,72 s. Beberapa titik lokasi lainnya (U/Obs12, T/Obs14, dan TL/Obs15) memiliki kedekatan hubungan saat air laut pasang dan surut kondisi perbani (Gambar 7). Hal ini dapat terjadi pada saat-saat tersebut terjadi gelombang laut sedikit lebih tinggi dibandingkan titik lainnya.

\section{KESIMPULAN DAN SARAN}

Pada saat musim peralihan I (April 2018), gelombang laut lebih tinggi terjadi pada awal dan akhir bulan. Faktor utama penyebab gelombang laut lebih tinggi adalah panjang fetch (arah pembangkitan gelombang oleh angin) yang lebih besar dari arah Samudera Hindia. Pengaruh lokal tinggi gelombang pada titik kajian disebabkan oleh terumbu karang, terutama bentuk pertumbuhan jenis massive dan submassive. Pada saat pasut tersurut dan tertinggi dari kondisi purnama dan perbani, kondisi gelombang laut adalah rendah $(<0,2$ $\mathrm{m})$.

Terjadi hubungan erat antara parameter gelombang laut di lokasi kajian terhadap sebaran lifeform karang. Nilai analisis PCA dari sebaran gelombang laut di wilayah kajian memiliki hubungan sebesar 77,97 \%. Nilai analisis CA dari keterkaitan antara lifeform karang di wilayah kajian sebesar 74,40 \%.

P. Sirandah memiliki tinggi gelombang laut paling besar, mencapai maksimum 1,07 $\mathrm{m}$ dengan periode 4,26 s, disebabkan perairan yang lebih terbuka dan fetch paling panjang. Terdapat karang jenis submassive (CS) lebih dominan mencapai 77,33-85,27 \%. Kondisi gelombang laut di perairan $P$. Pasumpahan lebih rendah, terutama pada bagian selatan dengan tinggi maksimal $0,64 \mathrm{~m}$ dan periode 3,26 s dan rata-rata keseluruhan selama sebulan sebesar 0,08-0,18 m. Terdapat banyak jenis lifeform karang di perairan ini yaitu semua jenis karang non-Acropora dan Acropora jenis bercabang (ACB).

P. Sikuai memiliki gelombang laut cukup rendah, maksimal sebesar 0,31 $\mathrm{m}$ dengan periode 2,25 s (TTG) dan 0,80 $\mathrm{m}$ dengan periode 3,71 s (B-BL). P. Sironjong memiliki gelombang laut mencapai $0,92 \mathrm{~m}$ (maksimum) dengan periode 3,93 s. Terumbu karang di perairan P. Sikuai dan P. Soronjong kurang baik $(0,2$ - 17,53 \%). Lifeform karang jenis submassive paling rendah pada ke dua pulau ini $(0,07 \%)$.

\section{UCAPAN TERIMA KASIH}

Ucapan terimakasih diberikan kepada semua pihak yang telah membantu terlaksananya seluruh kegiatan penelitian sampai selesai.

\section{DAFTAR PUSTAKA}

[ECMWF] Eropean Centre For Medium-Range Weather Forcasts. (2015). Data Gelombang Signifikan. [accessed 2015 Oct 29]. http://apps. ecmwf.int/datasets/.

[WMO] World Meteorological Organization. 1998. Guide to Wave Analysis and Forecasting. Second Ed. Geneva: World Meteorological Organization.

Astuti, E. H., Ismanto, A. \&, Saputro, S. (2016). Studi Pengaruh Gelombang Terhadap Transport Sedimen di Perairan Timbulsloko Kabupaten Demak Jawa Tengah. J Oseanografi UNDIP. 5(1):77-85.

Department of The Army. 2003. Coastal Enginerring Manual. Washington (US): U.S. Army Corps of Engineers.

Gourlay, M. R., \& Colleter, G. (2005). Wave-generated flow on coral reefs - an analysis for twodimensional horizontal reef-tops with steep faces. Coast Eng. 52:353-387. doi:10.1016/j. coastaleng.2004.11.007.

Hadikusumah. (2009). Karakteristik Gelombang dan Arus di Eretan, Indramayu. J Makara, Sains. 13(2):163-172.

Hardjono, S. (2018). Analisa Ketinggian Gelombang yang Sesuai untuk Pengoperasian Kapal Cepat Rudal 60M di Perairan Indonesia. J War Penelit Perhub. 30(1):43-58. doi:10.25104/warlit. v30i1.635.

Hardy, T.A.,\&Young, I.R.(2014). Waveattenuation onan offshore coral reef. J Geogr Res. 101(C6):14,31114,326. doi:10.1029/96JC00202.

Hidayat, J. J., Yusuf, M., \& Indrayanti, E. (2013). Dinamika Penjalaran Gelombang Menggunakan Model CMS-Wave di Pulau Parang Kepulauan Karimunjawa. J Oseanografi UNDIP. 2(3):255264. 
Holthuijsen, L.H. (2007). Waves in Oceanic and Coastal Waters. New York (US): Cambridge University Press.

Huang, Z., Lenain, L., Melville, W. K., Middleton, J. H., Reineman, B, Statom, N., \& Mccabe, R.M. (2012). Dissipation of w.ave energy and turbulence in a shallow coral reef lagoon. J Geophys Res. 117(C03015), 1-18. doi:10.1029/2011JC007202.

Huda, A. N., Suryoputro, A. A. D., \& Subardjo, P. (2015). Studi Pola Transformasi Gelombang di Perairan Kota Tegal. J Oseanografi UNDIP. 4(1), 341-349.

Jago, O. K., Kench, P. S., \& Brander, R.. W. (2007). Field observations of wave-driven waterlevel gradients across a coral reef flat Field observations of wave-driven water-level gradients across a coral reef flat. $J$ Geophys Res. 112(C06027), 1-14. doi:10.1029/2006JC003740.

Kench, P. S., \& Brander, R. W. (2015). Wave Processes on Coral Reef Flats: Implications for Reef Geomorphology Using Australian Case Studies. J Coast Res. 22(1), 209-223. doi:10.2112/05A-0016.1.

Kurniawan, R., Habibie, M. N., \& Suratno. (2011). Variasi Bulanan Gelombang Laut di Indonesia. $J$ Meteorol dan Geofis. 12(3), 221-232.

Parauba, R.., Jasin, M. I., \& Mamoto, J. D. (2016). Analisis Karakteristik Gelombang Pecah di Pantai Niampak Utara. J Sipil Statik. 4(10), 595-603.

Poerbandono. (2004). Pemecah Ombak Timbulkan Masalah Baru. Pikiran-Rakyat.

Pomeroy, A. W. M, Lowe, R. J., Van Dongeren, A. R., Ghisalberti,M.,Bodde,W., \& Roelvink, D. (2015). Spectral Wave-Driven Sediment Transport Across a Fringing Reef. Coast Eng. 98, 78-94. doi:10.1016/j.coastaleng.2015.01.005. http:// dx.doi.org/10.1016/j.coastaleng.2015.01.005.

Reidenbach, M. A., Koseff, J. R., Monismith, S. G., Steinbuck, J. V., \& Genin, A. (2006). The effects of wave and morphology on mass transfer within branched reef corals The effects of waves and morphology on mass transfer within branched reef corals. Limnol Oceanogr. 51(2), 1134-1141. doi:10.4319/1o.2006.51.2.1134.

Satriadi, A. (2017). Peramalan Tinggi dan Periode Gelombang Signifikan Di Perairan Dangkal (Studi Kasus Perairan Semarang). Bul Oseanografi Mar. 6(1), 17-23.

Sreeranga, S., \& Mendi,V. (2018). Empirical Modelling of Wave Transmission Over the Artificial Reef. Int $J$ Earth Sci Eng. 11(03), 247-254. doi:10.21276/ijee.2018.11.0307.

Storlazzi, C. D., Brown, E. K, Field, M. E., Rodgers, K., \& Jokiel, P. L. (2005). A model for wave control on coral breakage and species distribution in the Hawaiian Islands. Coral Reefs. 24:43-55. doi:10.1007/s00338-004-0430-x.

Sujantoko., \& Natakusumah, D. K. (2003). Model Simulasi Interaksi Gelombang dan Arus di Perairan Dangkal. J Tek Sipil. 10(3), 99-108.

The European Union Copernicus. (2020). Data Gelombang Laut.

Trujillo, A P., Thurman, H. V. (2011). Essentials of Oceanography. Tenth Edit. USA: Prentice Hall Pearson Education, Inc.

JURNAL KELAUTAN NASIONAL, Vol. 16, No 1, April 2021, Hal. 33-44 